\title{
最新の切削工具による高硬度金型材料の加工
}

\author{
廣瀬 武史 ${ }^{*}$
}

\section{Cutting Data on High Hardness Die Steels by New Cutting Tools}

\section{Takeshi Hirose}

\section{Synopsis}

Recent trends in die and mold industries have led the employment of high hardness and high performance die steels to improve die life. These steels, however, are becoming more difficult to be machined.

This paper discusses the cutting tests of this kind of steels which were conducted using indexable endmills and solid carbide tools. These tests evaluate the machinability of high hardness steels and show the optimum tools and cutting conditions.

\section{1 . 高硬度金型材料の動向}

金型はものづくりの基本となる道具であり，特に大量生 産の基盤とも言える.近年, 製造業の海外進出の活発化に より，国内産業の空洞化か懸念され，金型への要求も高 まった .具体的には，原価低減，品質向上，寿命向上，短 納期対応などである.こういった背景から，金型材料の開 発も急速に進んできている ${ }^{1)}$.

しかし,金型の高性能化, 長寿命化などに成果を発揮し ている高性能金型材料は,切削加工における被削性に問題 がある場合が多い.金型材料を加工する上での問題点とし ては, 切削加工の被削性以外にも, 放電加工性, 研削加工 性，さらに鏡面仕上げ性，シボ加工性などもある1)。ここ では, 高性能金型材料ではあるが, 切削加工の能率向上, 工具寿命向上が望まれている金型材料を取り上げ，乥の切 削加工評価に基づき, 被削性, 最適工具, 最適切削条件に ついてまとめる .

\section{2 . 金型材料の選定}

プラスチック金型は ,中国に代表される東アジアへの海 外流出が著しい，しかし, 鍛造金型, ダイカスト金型は流 出のペースがゆるやかである.高い切削技術を要する金型 材料を使用していることが，ひとつの要因と考えられる .
一般に, 焼入れ, 焼戻し後の高温強度に優れ, 䩛性も高い SKD61系が使用されている .

鍛造金型，ダイカスト金型として，さらなる寿命延長を 実現するため, SKD61 以上に, 耐ヒートチェック性, 䳬 性を向上させた材料のひとつにDH31-S がある.Fig.1 は， DH31-S と SKD61 の位置づけを示すグラフである ${ }^{2)}$.

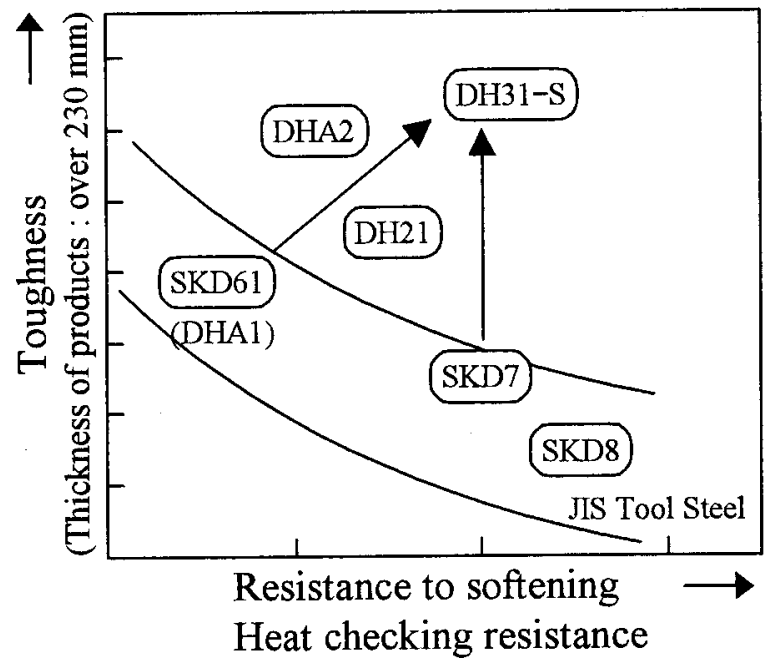

Fig.1. Concept of DH31-S. 
そここで今回は, 金型材料としての評価は高いが, 加工能 率向上,工具寿命向上が望まれている DH31-S を, SKD61 との比較という観点で評価，調査することとした .

\section{3 .切削工具の選定}

高硬度・高性能鋼を切削加工している金型メーカーや鍛 造およびダイカストのユーザーでは, 特に, 形状部の荒加 工と穴あけ加工が改善のポイントとなっている場合が多 い.乥こで ,このうたたつ加工法を評価してみることとし た。

まず，形状部の荒加工については，高送り用ラジアス カッタで評価することとした。従来，高能率加工を行なう には，丸駒チップを使ったラジアスカッタを使うのが主流 であった .刃先強度が高く, 大切込み, 高送りでも安定し た加工が可能であり，経済性にも優れる．

しかし, 弚の欠点として壁面との接触面積が大きいた め，突き出しの大きい場合やコーナ部でびびりやすいとい う傾向があった .乥こで, この欠点を補うラジアスカッタ の開発が急速に進んできている .

Fig. $2^{3)}$ は，今回選定した高送りラジアスカッタ「AJX 形」の切れ刀形状である. $2 \mathrm{~mm}$ 以下の切込み領域におい ては, 大 R の丸駒チップと同等以上の安定した高送り加 工が可能である . また , 外周刃は小 $\mathrm{R}$ で内側に逃げてい るため,壁面との接触面積が小さく，びびりにくい特長を 持っている、つまり，丸駒チップの欠点を補ったチップ形 状である.弚こでこの工具は, 今回の評価に最適と判断し た。

穴あけ加工については,当社の主力汎用ドリルであるミ ラクル ZET1 ドリルで, 弚の被削性評価を行なうこととし た、鍛造金型やダイカスト型は，硬さ $40 \mathrm{HRC}$ から $50 \mathrm{HRC}$ 前後て使用されるため, 特に高硬度材料に特化したドリル
ではなく，汎用タイプを選定した 。

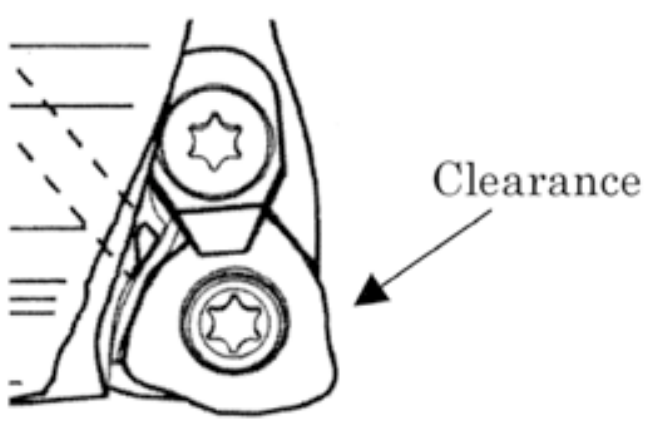

Fig.2. Insert shape of AJX.

\section{4 .荒加工用ラジアスカッタ による評価}

\section{1 評価方法, 条件}

評価の主目的は，高能率で長寿命な切削領域を選定する ことである.よって，AJX のコンセプトである低切込み， 高送りを基本とし，切削速度なども含め展開してみた 。

評価条件，展開内容をTable 1 に示す．

最適領域を選定する評価であるため，樣々な条件の組合 せで，工具が寿命に到るまでの加工時間を比較評価してみ た.評価は, 切れ刃 1 枚にて行い, 寿命基準は, 突発的な 欠損か, 正常摩耗の場合, 逃げ面摩耗幅が $0.2 \mathrm{~mm}$ に到る までとした .ドライ加工の場合でも，エアブローは使用し た .ウェット加工の場合の切削油剂にはシンセティックタ イプを使用した .

まず，48HRCについて，樣々な条件展開て評価を行い， 弚の中から最適領域を選定した.52HRC については， 48HRC の結果を基準とし, 弚の前後への展開という形で 進めた .

Table 1. Cutting conditions

\begin{tabular}{c|c|c}
\hline Conditions & No. 1 & No. 2 \\
\hline Work piece & DH31-S(48HRC) & DH31-S(52HRC) \\
\hline Tool & \multicolumn{2}{|c}{ AJX12-050A03(04)R $(\varphi$ 50) } \\
\hline Insert & JDMW120420ZDSR-FT \\
\hline Grade & $50,60,70,80$ & VP15TF \\
\hline Cutting speed $(\mathrm{m} / \mathrm{min})$ & $1.0 \sim 2.0$ & $40,50,60,70$ \\
\hline Depth of cut $(\mathrm{mm})$ & $0.7 \sim 2.0$ & 1.0 \\
\hline Width of cut $(\mathrm{mm})$ & \multicolumn{3}{c}{ Dry and Wet } \\
\hline Feed $(\mathrm{mm} /$ tooth) & \multicolumn{3}{|c}{ M/C } \\
\hline Coolant & \multicolumn{3}{c}{} \\
\hline Machine & \multicolumn{3}{c}{} \\
\hline
\end{tabular}




\section{2 評価結果}

まず，Fig. 3 に，硬さ $48 \mathrm{HRC}$ について，評価結果の比 較を示す.実際にはさらに多くの条件に展開し評価してみ たが ,最も長寿命であった条件と弚の前後を要約して示し ている。
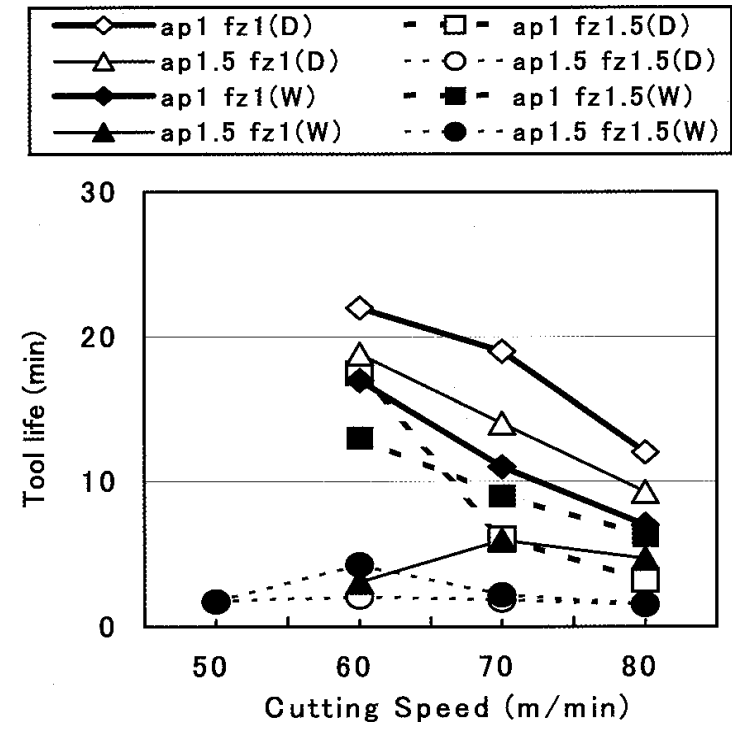

Fig.3. Comparison of Tool Life. ap; Depth of cut, fz; Feed, W; Wet, D; Dry

まず，最適領域についてであるが，長時間という観点で はなく，仕事量という観点で分析してみた．つまり，いか に多くの切りくずを排出したかである . 切込み量 , 送り 量 , 切削時間，切削速度から算出すると，最も仕事量が大 きかったのは, 切込み量 $1.5 \mathrm{~mm}, 1$ 刃の送り量 $1 \mathrm{~mm}$ ，切 削速度 $60 \mathrm{~m} / \mathrm{min}$ の場合であった .1切れ刃で $377 \mathrm{cc}$ 排出し たことになる．切込み量 $1 \mathrm{~mm}, 1$ 刃の送り量 $1.5 \mathrm{~mm}$ の場 合も僅差であり，この付近に最適領域があると判断できる が，切込み量 $1.5 \mathrm{~mm} ， 1$ 刃の送り量 $1.5 \mathrm{~mm}$ の場合は，大 幅に寿命が低下する結果となった .

次に , ドライ加工とウェット加工を比較すると , ドライ 加工のほうが長寿命である結果が多く，特に上位を占めて いるという印象である .これは, 転削加工全般の傾向と同 じである .

Fig. 4 に，SKD61 を含む評価結果の比較を示す．

各条件とも SKD61 のほうが長寿命であり，切込み量 $1 \mathrm{~mm}, 1$ 刃の送り量 $1.5 \mathrm{~mm}$ の場合で約 2 倍, 切込み量 $1.5 \mathrm{~mm} ， 1$ 刃の送り量 $1 \mathrm{~mm}$ の場合で約 3.5 倍という結果 である .

Fig. 5 に 硬さ 52HRCの場合について ,DH31-S と SKD61

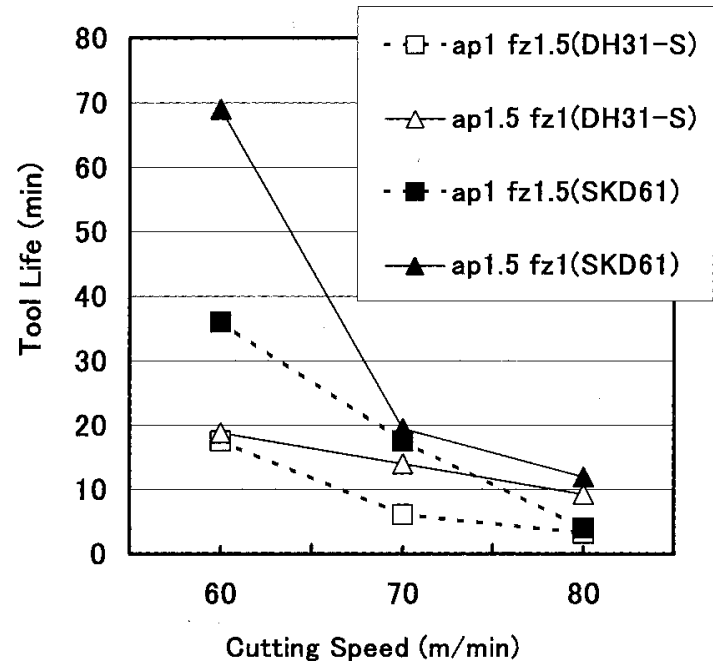

Fig.4. Comparison of Tool Life (DH31-S,SKD61).

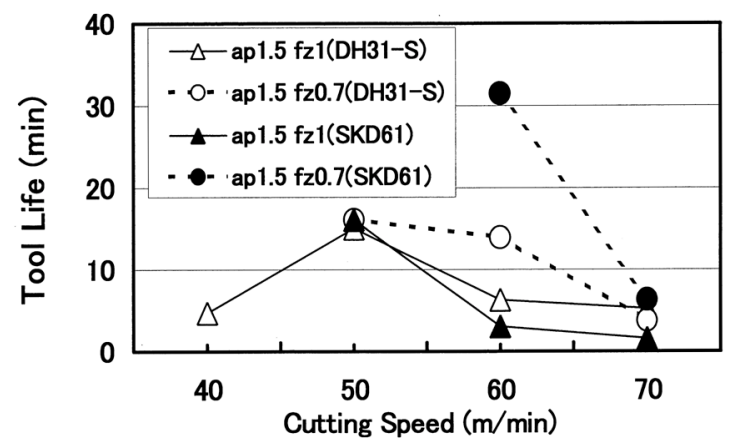

Fig.5. Comparison of Tool Life (48HRC,52HRC).

の工具寿命を比較した結果を示す．

硬さ $52 \mathrm{HRC}$ の場合, 切削速度は $50 \mathrm{~m} / \mathrm{min}$ のほうが長寿 命であった．しかし，48HRC の場合と同じく，切込み量 $1.5 \mathrm{~mm}, 1$ 刃の送り量 $1 \mathrm{~mm}$ の付近に最適領域があると判 断できる.

\section{3 結果の検討}

工具寿命で判断した場合 ,DH31-S は SKD61 より被削性 が悪いという結果になった.多くの金型メーカーの指摘と 同じである .

しかし，切削条件別にみてみると，大きく劣る場合と， 僅差，逆転という場合もある．また，1刃の送り量 $1 \mathrm{~mm}$ という高能率加工で, $377 \mathrm{cc}$ の切りくずを排出することが できることも実証できた .

今回の結果から，単純に切削条件を下げるという選択の みでなく，適正な切削条件領域を選定することにより，大 幅な改善が可能であると言える . 


\section{5 .穴あけ加工評価}

\section{1 評価方法, 条件}

荒加工用ラジアスカッタによる評価結果より，特に切削 速度に着目し，最適領域の評価，選定を行なうこととした．

評価条件，展開内容をTable 2 に示す。

Table 2. Cutting conditions

\begin{tabular}{c|c}
\hline Work piece & DH31-S $(48 \mathrm{HRC})$ \\
\hline Tool & MZS1000LB $(\varphi$ 10) \\
\hline Grade & VP15TF \\
\hline Cutting speed $(\mathrm{m} / \mathrm{min})$ & $20,30,40$ \\
\hline Revolution $\left(\mathrm{min}^{-1}\right)$ & $637,955,1592$ \\
\hline Feed $(\mathrm{mm} / \mathrm{rev})$ & $0.1,0.15$ \\
\hline Depth of cut $(\mathrm{mm})$ & 50 \\
\hline Coolant & Wet \\
\hline Machine & M/C
\end{tabular}

穴あけ加工についても，最適領域を選定する評価である ため,樣々な条件の組合せで, 工具が寿命に到るまでの加 工穴数を比較評価してみた .評価の寿命基準は, 逃げ面摩 耗幅が $0.3 \mathrm{~mm}$ に到るまでとした .

評価は全てウェット加工とし，切削油刘には塩素フリー のエマルションタイプを使用した .

\section{2 評価結果}

Fig. 6 に，1回転当りの送り量 $0.1 \mathrm{~mm}$ の場合について， DH31-S と SKD61 の工具寿命を比較した結果を示す .Table 2 に示す樣々な切削条件の組合せて評価を行なったが, 最も 長寿命であった条件と光の前後を要約して示している．

まず，DH31-S の最適領域についてであるが，1回転当り の送り量 $0.1 \mathrm{~mm}$, 切削速度 $30 \mathrm{~m} / \mathrm{min}$ の場合が 39 穴であり， 最も長寿命であった . 前後の切削速度の場合よりも明確な 優位性か確認できた .

SKD61 では, 切削速度 30m/min の場合が 46 穴と長寿命 であるが ,切削速度 40m/min の場合は 17 穴で,DH31-S の 24 穴より劣る結果となった .

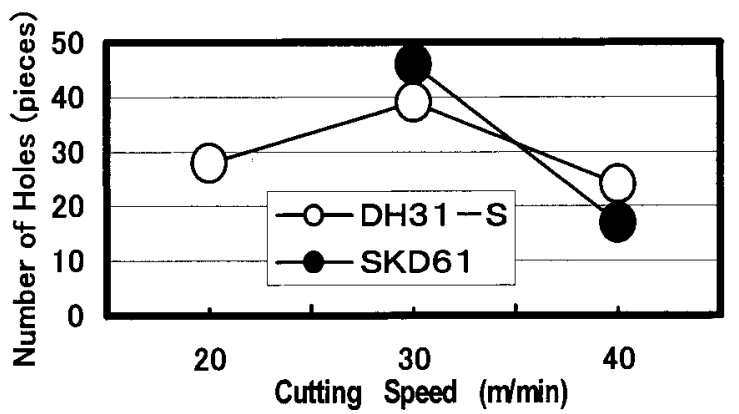

Fig.6. Comparison of Tool Life (DH31-S,SKD61).

\section{3 結果の検討}

工具寿命で判断した場合，穴あけ加工の評価において も,DH31-S は SKD61 より被削性が悪いという傾向があっ た.しかし, 弚の最適領域の付近での差は小さく, 荒加工 用ラジアスカッタによる評価結果と同樣, 適正な切削条件 領域を選定することにより,大幅な改善が可能であること がわかった .

\section{6.まとめ}

今，製造業は海外の低価格製品の脅威にさらされてお り,製造コストの低減が強く望まれている.金型業界にお いても，光の傾向は顕著であり，製造コス卜低減，製造工 期短縮が課題であり, 切削工具の長寿命化, 高能率加工が 重要な改善課題である.

今回は, 金型業界において加工能率向上,工具寿命向上 か望まれている金型材料に注目し, 最適切削工具, 最適な 切削条件の領域を調査した.今後, 金型材料メーカーとの 連携も強化し, 加工現場に役立つ情報を提供していきた い.

\section{(文 献)}

1)並木邦夫: 電気製鋼 ,71(2000), 157

2)製品紹介:電気製鋼,71(2000), 183

3)三菱マテリアル:技術資料「高送りラジアスカッタAJX 形」(2002) 